\title{
The Economic Value of Controlling an Invasive Shrub
}

Author(s): Erika Zavaleta

Source: AMBIO: A Journal of the Human Environment, 29(8):462-467. 2000.

Published By: Royal Swedish Academy of Sciences

DOI: $10.1579 / 0044-7447-29.8 .462$

URL: http://www.bioone.org/doi/full/10.1579/0044-7447-29.8.462

BioOne (www.bioone.org) is an electronic aggregator of bioscience research content, and the online home to over 160 journals and books published by not-for-profit societies, associations, museums, institutions, and presses.

Your use of this PDF, the BioOne Web site, and all posted and associated content indicates your acceptance of BioOne's Terms of Use, available at www.bioone.org/page/terms_of_use.

Usage of BioOne content is strictly limited to personal, educational, and non-commercial use. Commercial inquiries or rights and permissions requests should be directed to the individual publisher as copyright holder. 


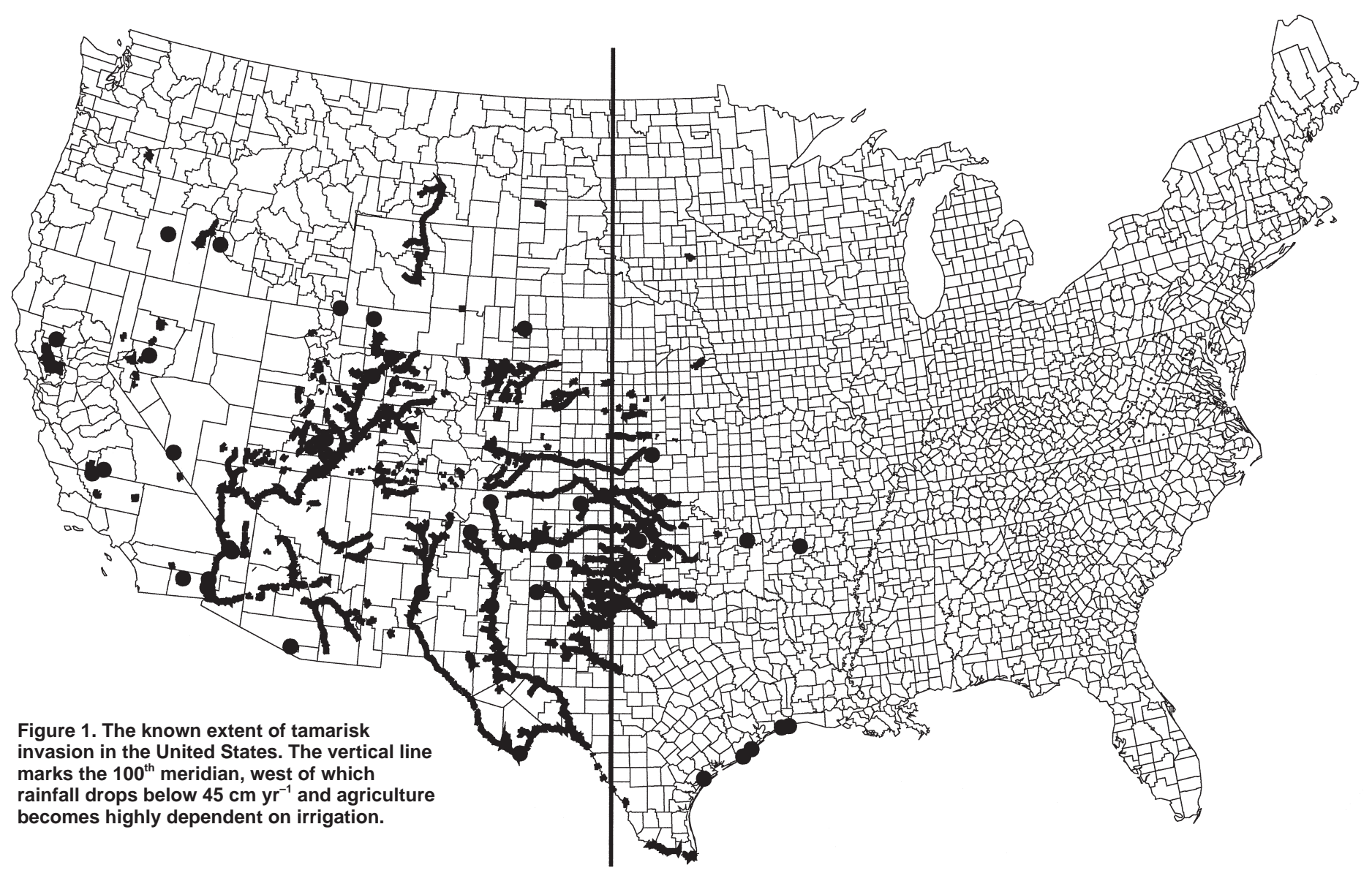

tamarisk has spread rapidly into nearly every perennial drainage in the arid and semiarid regions of the western United States (Fig. 1). It has benefitted from human interference with the natural flood cycles of rivers, invading dammed waterways with particular speed (16). To date, it has replaced native riparian forest and scrub communities in 470 000-650000 ha of riparian floodplain habitat in 23 states, from sea level to $2500 \mathrm{~m}(16,17)$. It is especially pervasive in the dry, southwestern states of Arizona, New Mexico, west Texas, Nevada, Utah, and southern California, but is also widespread in the Rocky Mountain states, the western Plains states, and parts of Oregon and Idaho. While less information exists on its naturalized range outside of the United States, tamarisk is known to occur throughout large areas of northwestern Mexico (18).

Tamarisk possesses many classic weedy characteristics to which it owes its rapid spread and effective displacement of native vegetation. It produces tremendous numbers of seeds which germinate quickly in a wide range of conditions, and the resulting plants can grow rapidly, up to $4 \mathrm{~cm}^{\text {day }}{ }^{-1}(16,19,20)$. In the process, tamarisk plants consume tremendous quantities of water and draw salts up to the surface from deep in the soil. These salts, secreted on the invader's leaves, give rise to increasingly saline soils not tolerated by native riparian species, such as Goodding willow (Salix gooddingii) and Fremont cottonwood (Populus fremontii) (21). Tamarisk can tolerate both drought and flooding to degrees that native species cannot $(22,23)$. It can withstand submersion for up to 3 months, but it can also survive prolonged desiccation and is more able than native species to establish in areas with deep zones of permanent water availability (15). Fire may also be assisting the spread of tamarisk, both because the invader resprouts readily from belowground parts, and because the accumulation of its litter increases the probability of fire and salinizes the soil when fires do occur (24, $25)$.

At present, tamarisk continues to expand its range and may have spread as much as 200000 ha during 1989-1999 (18). In particular, it has made recent advances into higher elevations in arid regions and into wetter areas such as central California and the Texas Gulf Coast. Long-term warming and drying trends are likely to further expand the potential range of the invader north, uphill, and into regions of higher rainfall (Zavaleta and Royval, unpubl. data).

\section{THE IMPACTS OF TAMARISK ON ECOSYSTEM SERVICES}

In the arid western states, municipalities, farmers, the hydropower industry, fishermen, and other recreationists all clamor for access to surface and groundwater. Tamarisk stands, with their dense and leafy canopies and rapid growth rates, consume water more rapidly than native vegetation, drawing down watertables, drying desert springs, and lowering river flow rates and lake levels $(15,20,26)$. Nearly 20 studies of transpiration rates by tamarisk and native riparian species have been conducted (26). Transpiration rates vary with weather, stand density, and water availability, but under no condition has tamarisk been found to transpire less than native vegetation. On average, after accounting for possible returns of transpired water to the region, tamarisk stands consume 3000 to $4600 \mathrm{~m}^{3} \mathrm{ha}^{-1} \mathrm{yr}^{-1}$ more water than the native vegetation that they replace. Marginal water losses to tamarisk are hence comparable to annual precipitation totals, which remain below $4500 \mathrm{~m}^{3} \mathrm{ha}^{-1} \mathrm{yr}^{-1}$ throughout the invaded region and below $2000 \mathrm{~m}^{3} \mathrm{ha}^{-1} \mathrm{yr}^{-1}$ in much of it.

Tamarisk also increases the area covered by riparian vegetation in two ways. It reaches deeper for groundwater farther from waterways, and it builds up banks and islands, which it then colonizes, through sediment capture (27). Tamarisk invasion therefore represents not only a ha-per-ha replacement of less thirsty vegetation by a species that consumes more water; it also increases the extent of heavily vegetated (and therefore heavily transpiring) areas near waterways. Given estimates of tamarisk's current areal extent (470 000-650 000 ha) and marginal water 
losses associated with its invasion (3000-4600 $\mathrm{m}^{3} \mathrm{ha}^{-1} \mathrm{yr}^{-1}$ ), tamarisk currently costs the western United States approximately 1.4-3.0 billion $\mathrm{m}^{3}$ of water every year. The economic losses associated with this transpiration loss include consumptive enduses by households and irrigators as well as nonconsumptive uses like hydroelectric power generation and fishing. In a region of plentiful water, the marginal value of water lost to tamarisk might be negligible, but in an environment of shortage, where there are real, positive costs associated with replacing the water lost to tamarisk, its marginal value is considerable.

A second major impact of tamarisk on the functioning of riparian ecosystems concerns flood control. When tamarisk invades

\begin{tabular}{|c|c|c|c|}
\hline Project & $\begin{array}{l}\text { Annual water } \\
\text { yield }\left(\mathrm{m}^{3}\right)\end{array}$ & $\begin{array}{l}\text { Cost } \\
\text { (USD } 1000 \mathrm{~m}^{-3} \text { ) }\end{array}$ & $\begin{array}{l}\text { Total cost over } \\
55-y e a r \text { lifespan } \\
\text { (USD mill. 1998) }\end{array}$ \\
\hline $\begin{array}{l}\text { 55-year } \\
\text { All American } \\
\text { Canal Lining } \\
\text { Agreement }\end{array}$ & 8.35 million & 25.73 & 118.1 \\
\hline $\begin{array}{l}\text { 55-year } \\
\text { Coachella } \\
\text { Canal Lining }\end{array}$ & 3.17 million & 41.07 & 71.5 \\
\hline \multirow{2}{*}{$\begin{array}{l}\text { Agricultural } \\
\text { Drainage } \\
\text { Water Desalting }\end{array}$} & 185-370 million & $120-128$ & $1300-3010$ \\
\hline & & $\begin{array}{l}\text { Total combined } \\
\text { costs: }\end{array}$ & $1180-3200$ \\
\hline
\end{tabular}

Source: J. Matusak (Metropolitan Water District), unpublished

Table 2. Annual values of irrigation water lost to Tamarix by subregion

\begin{tabular}{|c|c|c|c|c|}
\hline & \multicolumn{2}{|c|}{$\begin{array}{l}\text { Water value }^{1} \\
\left(\text { USD } 19981000 \mathrm{~m}^{-3} \text { ) }\right.\end{array}$} & \multicolumn{2}{|c|}{$\begin{array}{l}\text { Total annual losses } \\
\text { (USD 1998) }\end{array}$} \\
\hline & $\operatorname{low}^{2}$ & high $^{3}$ & $\operatorname{low}^{4}$ & high $^{5}$ \\
\hline $\begin{array}{l}\text { Subregion } \\
\text { Arizona }\end{array}$ & 11.80 & 698 & 819000 & 20178000 \\
\hline Texas High Plains & 43.00 & 159 & 28476000 & 72548000 \\
\hline Oklahoma $^{6}$ & 43.00 & 159 & 3290000 & 11325000 \\
\hline Rocky Mountains & 12.70 & 24.30 & 16000 & 43000 \\
\hline $\begin{array}{l}\text { Ogallala region } \\
\text { (Kansas, South } \\
\text { Dakota, eastern } \\
\text { Colorado) }\end{array}$ & 52.50 & 59.10 & 2835000 & 7971000 \\
\hline Idaho and Wyoming & 13.10 & 19.70 & 42000 & 97000 \\
\hline $\begin{array}{l}\text { New Mexico, Texas }{ }^{6} \text {, } \\
\text { Great Basin }\end{array}$ & 11.80 & 11.80 & 3170000 & 9133000 \\
\hline
\end{tabular}

All values are adjusted to 1998 dollars using the general U. S. CPI. Crop CPI values were not selected because farm input prices reflect price changes in a number of categories. The value of a unit of water price changes in a number of categories. The value of a unit of water
is not expected to change in response to Tamarix control because the

2,3 Lroportional change in water supply due to eradication would be small. in the specified region. Per-unit economic values of water reflect both crop type and weather.

Low estimates of annual lost irrigation water value for the specified region are calculated using only the lowest unit water value reported for each region, and using the low estimates of Tamarix areal extent and water use.

High estimates for each region are calculated using a weighted average of $80 \%$ low per-unit water value and $20 \%$ high per-unit water value, reflecting an approximate distribution of crops typically grown in value, reflecting an approximate distribution of crops typically grown
the western United States (36). The values reported here were calculated using the higher estimate of Tamarix areal extent and the mean value of its water use reported across all studies.

No values were available in the literature for Oklahoma, which is assumed to share agricultural characteristics of the Texas High Plains; and for the arid Great Basin and Chihuahuan desert regions, which are conservatively assumed to share Arizona's lowest water value for all crops. a riparian corridor, it establishes in dense and extensively rooted thickets. These qualities - the same ones that make it a valuable tool for erosion control - also cause tamarisk to stabilize and trap sediment on sandbars, riverbanks, and midstream islands (28). Steady accretion enlarges banks and islands, narrowing river channels and reducing their waterholding capacity. These effects are not subtle: the Brazos River in Texas, for example, has narrowed nearly $90 \mathrm{~m}$ since its invasion by tamarisk in about 1940 (27). Comparisons of current aerial photographs with those taken by John Wesley Powell's 1871 expedition, show that the Green River in Utah's Canyonlands National Park has narrowed by almost a third since tamarisk reached it near the end of the $19^{\text {th }}$ century (29).

When storms and rapid snowmelt cause western rivers to rise, the reduced capacity of tamarisk-infested channels leads to flooding at lower river stages than was the case before invasion. When these flood waters flow over the banks of infested rivers, the density of the exotic vegetation traps debris and impedes downstream flow, backing up water and exacerbating flooding. Major flooding in Arizona in 1977-1979, with damages exceeding USD 150 mill. (18), first drew attention to tamarisk's role in worsening the frequency and severity of flood damage.

The negative impacts on wildlife of the displacement of native plant communities by dense, monospecific tamarisk stands are substantial. In short, tamarisk lacks palatable fruits and seeds, fails to harbor plant-eating insects that insectivorous birds, reptiles, and mammals can eat, occurs in high-density stands with little structural or microclimatic diversity, and is too small in stature or limb size to support large birds such as raptors and woodpeckers (30). In the southwestern deserts, tamarisk dries up springs and oases - necessary habitat and water sources for wildlife ranging from bighorn sheep and quail to endangered pupfishes $(9,20,30)$. Losses of insect diversity and abundance associated with tamarisk also compromise pollinator services, crucial and economically valuable inputs to crop production (31). Despite controversy over the importance of tamarisk stands to the endangered Southwest willow flycatcher (Empidonax trailii extimus), available evidence indicates that native riparian vegetation provides superior habitat to the songbird (32-34). Protecting flycatcher populations during restoration from tamarisk to native stands will, however, require careful planning.

\section{THE COSTS OF TOLERATING TAMARISK}

While techniques exist for the assigning of value to nonmarket ecosystem services such as wildlife protection and aesthetic value, a conservative assessment of recoverable economic damage by tamarisk must begin with market goods and services. I used current, measurable market values to estimate tamarisk's economic impacts on water supplies for municipalities, farmers, and hydropower generation, and on flood control as a conservative first approximation of the invader's regional economic impacts.

\section{Municipal Water Losses}

Two urban areas in the region affected by tamarisk are actively pursuing, at significant cost, schemes to augment their water supplies: southern California's Metropolitan Water District (including Los Angeles) and the four major cities of central Arizona (Phoenix, Tucson, Scottsdale, and Mesa) (18). In each case, additional water generated by replacing tamarisk with native vegetation would help to meet municipal water demands.

An estimated 260-570 mill. $\mathrm{m}^{3}$ of water that otherwise would be available to southern California are lost every year through transpiration by tamarisk on the Colorado River. Meanwhile, the Metropolitan Water District (MWD) has had to turn to purchasing extra water from farmers with priority water rights and to long-term, costly schemes to augment its water supplies. Three 
planned MWD projects that would conserve and desalinate agricultural water in order to make it available for municipal use could provide the same $260-570$ mill. $\mathrm{m}^{3} \mathrm{yr}^{-1}$ of water at a cost of USD 22-58 mill. $\mathrm{yr}^{-1}$ (Table 1). If the water currently lost to tamarisk were recovered through eradication of the invader, all or nearly all of the costs associated with these projects could be avoided. These costs therefore represent the annual value of the water lost to tamarisk from the Colorado River system alone.

Near Arizona's major cities, municipal users also compete with farmers for water supplies. An open water market exists in the area in which utility companies purchase and fallow agricultural land in order to increase water supplies to sell to municipal users (18; and pers. comm.). The mean price paid for this land is just over USD 120 per $1000 \mathrm{~m}^{3}$ of water recovered through fallowing (18). Tamarisk has infested 13 000-17 000 ha along the Salt and Gila Rivers and their tributaries near Arizona's big cities (18), consuming 4.0-7.9 mill. $\mathrm{m}^{3}$ more water than the native vegetation it replaced. The value of this water, based on the current market value of land purchased to replace it through fallowing is, hence, USD 4.9-9.6 mill. each year. The total value of southern California and Arizona municipal water supplies lost to tamarisk every year is an estimated USD 26-67 million.

\section{Agricultural Water Losses}

Throughout tamarisk's naturalized range, agriculture relies on irrigation either to allow the growing of less drought-tolerant crops or to increase yields to profitable levels (18). Several reviews of work on the marginal value of water used for agricultural irrigation provide region- and crop-specific estimates for much of the tamarisk's range (35-38). Most of these studies subtract all nonwater inputs to crop production from the total revenue generated by a crop, then treat the residual as the value of

\begin{tabular}{|c|c|c|c|}
\hline Dam & $\begin{array}{l}\text { Value of } \\
\text { water } \\
\text { (USD 1998 } \\
1000 \mathrm{~m}^{-3} \text { ) }\end{array}$ & $\begin{array}{l}\text { Estimated upstream } \\
\text { invaded area (ha) }\end{array}$ & $\begin{array}{l}\text { Annual lost value } \\
\text { (USD 1998) }\end{array}$ \\
\hline \multirow[t]{2}{*}{$\begin{array}{l}\text { Glen Canyon } \\
\text { Hoover } \\
\text { Parker } \\
\text { Davis }\end{array}$} & $\begin{array}{l}19.20 \\
36.70 \\
21.10 \\
24.20\end{array}$ & $\begin{array}{l}40220-79450 \\
50450-92780 \\
57670-102290 \\
57670-102290\end{array}$ & $\begin{array}{l}2357000-6985000 \\
5634000-15540000 \\
3701000-9845000 \\
4245000-11294000\end{array}$ \\
\hline & & Total & $15937000-43664000$ \\
\hline
\end{tabular}

Table 4. Summary of annual values lost to Tamarix in the western United States (USD mill. 1998).

Ecosystem service low high

Irrigation water Municipal water Hydropower (Colorado River) Flood contro

Total

$\begin{array}{cc}38.6 & 121 \\ 26.3 & 67.8 \\ 15.9 & 43.7 \\ 52.0 & 52.0 \\ 133 & 285\end{array}$

Table 5. Estimated costs of comprehensive eradication and restoration.

Activity Cost (USD 1998 ha $^{-1}$ )

\section{Site evaluation (year 1)}

Root plowing (year 2)

Hand application of herbicide (years 3-6)

Revegetation (years 7-14)

Monitoring (years 15-20)

Total $\mathrm{yr}^{-1}$. in its place. the water that went into the crop. Crop-specific values for 1000 $\mathrm{m}^{3}$ of water range from under USD 17 for some grain crops to over USD 650 for specialty crops like melons (Table 2). The estimated annual value of water lost to irrigators because of tamarisk's water consumption ranges from USD 38 mill., for the lowest water values in each state, to USD 120 mill. for cropweighted water values (36).

\section{Hydropower Generation}

In most of the western United States, water recovered through tamarisk eradication would most likely be removed for agricultural end-uses. Since this water would be withdrawn immediately from surface flows for irrigation, it would not have the opportunity to provide instream use values. In the Colorado River system, however, the highest-valued end use is by downstream municipal users. The optimal course of action would leave upstream water generated by tamarisk eradication in the river, allowing it to generate instream flow values, such as hydropower, as it travels to southern California.

Four dams on the lower Colorado River generate hydroelectric power to growing energy markets in the southwestern United States. Each is able to generate a given amount of electricity, based on the dam's height, per $\mathrm{m}^{3}$ of water that drops through its turbines. The costs of providing this electricity through alternative means, such as coal-fired steam or gas turbine generation, have been estimated at USD 60-146 per $1000 \mathrm{~m}^{3}$ (37). Specific estimates are available of the value of water for electricity generation at each of the 4 dams on the lower Colorado. Based on these findings and the calculated areas of tamarisk infestion above each of the dams, the value of hydropower generation lost to the invader is approximately USD 16-44 mill. $\mathrm{yr}^{-1}$ (Table 3).

\section{Flood Control Losses}

In 1989, a consulting firm employed an Army Corps of Engineers hydrological flow model to simluate the effects of tamarisk on flood events in 2 major rivers of the western United States (18). They extrapolated their results to other invaded areas and developed economic damage estimates associated with the presence of tamarisk. Their figures represent at best a rough estimate of the flood control costs associated with tolerating tamarisk. Nevertheless, their estimates are conservative for at least three reasons. First, they considered $90 \%$, not $100 \%$, removal of tamarisk and considered damages based on the 1989, not the larger 1999 areal extent of the invader along rivers. Second, their study ignored the effect of long-term channel narrowing by tamarisk and considered only the increased resistance of dense tamarisk thickets to overbank flow. Channel narrowing arguably has the greatest impact on flood damages because by substantially reducing channel capacity, it greatly increases the likelihood that overbank flow will occur at all. Finally, economic flood damage estimates reflect the amount of urban, agricultural, and other development that exists in river floodplains. With rapid population expansion, development within the boundaries of potential flood areas is likely to have increased since their 1989 study. Converting these results to 1998 USD yields an estimate of the average impact of tamarisk on flood damages of USD 52 mill.

\section{COMPARING THE COSTS AND BENEFITS OF RESTORATION}

In total, the presence of tamarisk in the western United States will cost an estimated annual USD 127-291 mill. in lost ecosystem services (Table 4). This loss amounts to USD 284-447 $\mathrm{ha}^{-1}$ of land currently infested by the invader. These represent the benefits to be recovered by removing tamarisk from its current naturalized range and restoring native riparian communities 


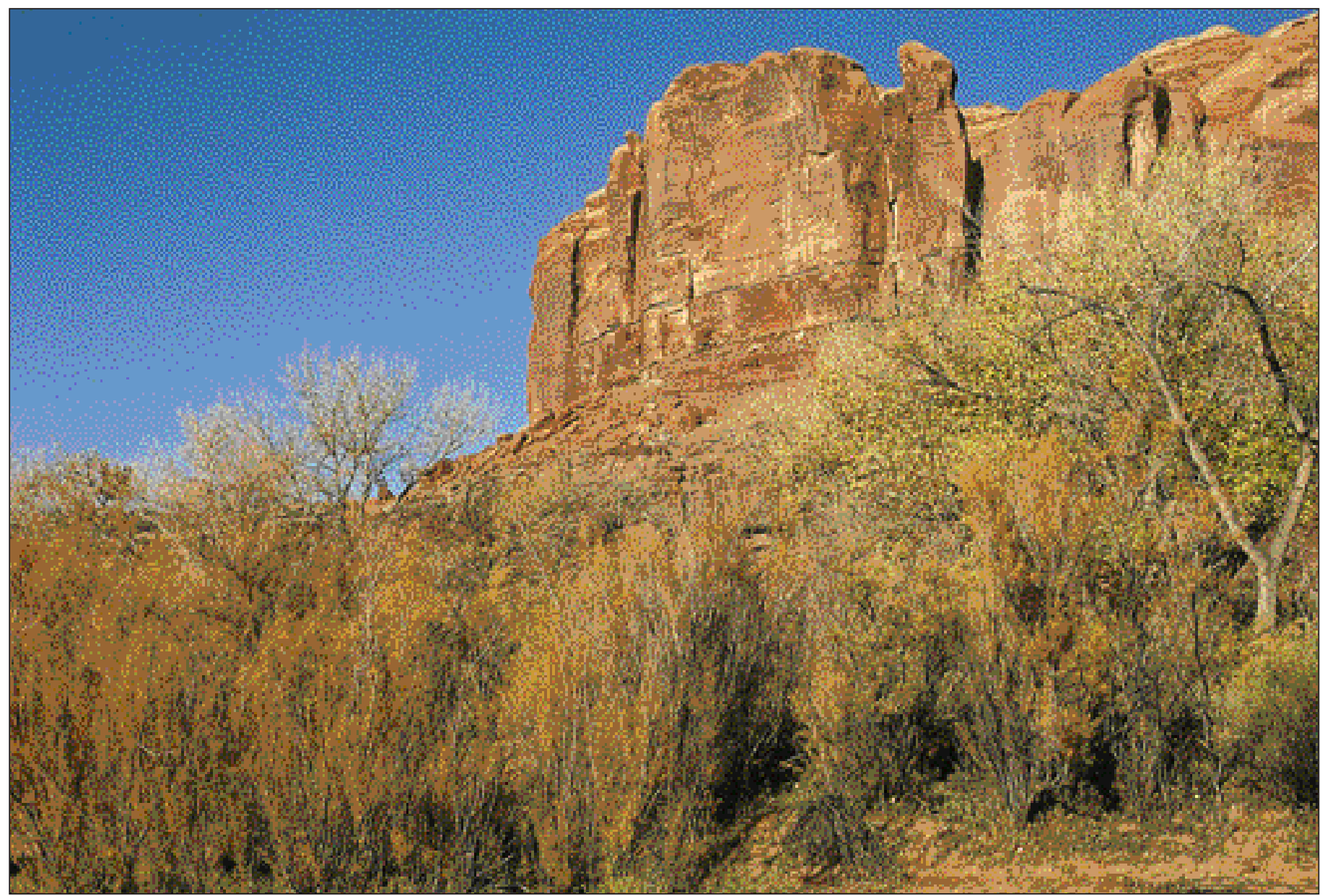

Tamarisk shedding foliage in autumn in Moab, Utah, USA. Its leaves will salinize the soil and increase the potential for wildfires. Photo: K. Bonine.

Highly successful tamarisk eradication and revegetation projects conducted on a local scale have ranged in cost from USD $500 \mathrm{ha}^{-1}$ in central Texas, where post-planting care of the native species replacing tamarisk is unnecessary, to over USD $12000 \mathrm{ha}^{-1}$ in the most arid pockets of the southwest, where several years of watering of native transplants must take place to ensure their establishment (39). Tamarisk is a candidate for biocontrol with imported insects $(34,40)$, but until this approach has been more thoroughly tested it cannot be considered a substitute for the prevailing, conventional methods.

I evaluated the costs of controlling tamarisk and restoring native communities based on a comprehensive, 20-year program of planning, eradication, revegetation, and monitoring (Table 5). Initial site evaluation, which typically costs USD 75-125 ha would guide the selection of native species to plant, minimizing the costs associated with revegetation failure (39). The actual removal of tamarisk through cutting and root plowing the following year would cost approximately USD $145 \mathrm{ha}^{-1}$. The hand application of relatively expensive, but environmentally safe, water-based herbicides to root stumps in years 3 to 6 would minimize the chances of resprouting and seed germination at an estimated cost of slightly over USD $1500 \mathrm{ha}^{-1}$ (39).

While revegetation costs vary substantially, the mean cost per ha is likely to be low because economies of scale drastically reduce costs (18); initial site evaluation will guide selection of the most suitable species for each location; some areas such as the near-bank portions of tamarisk-narrowed rivers will not be revegetated at all; and recent, successful programs in arid areas have been able to revegetate for well under USD 5000 (41). I computed a mean value of just under USD $5000 \mathrm{ha}^{-1}$ over years 7 to 14 for greenhouse rearing, transplanting, and watering of native trees and shrubs. Finally, monitoring the course of revegetation and checking for recolonization by tamarisk typically add $10 \%$ to a project's costs (39), approximately USD 680 $\mathrm{ha}^{-1}$ in this case.

The 20-year total cost of this program is USD $7400 \mathrm{ha}^{-1}$, approximately USD 2400 more than the most successful eradication campaign currently underway in the region (41). At a discount rate of $0 \%$, these control costs would be offset by economic benefits within 17-26 years of the invader's initial removal (Table 6). Since initial removal occurs at the beginning of the restoration process, benefits essentially keep pace with

Table 6. Number of years required to recover the costs of controlling Tamarix throughout the western United States.

Discount rate (\%) Number of years ${ }^{1}$

$\begin{array}{ll}0 & 17-26 \\ 1 & 17-28 \\ 2 & 17-29 \\ 3 & 17-31 \\ 4 & 16-34 \\ 5 & 16-39 \\ 6 & 16-50\end{array}$

The range in values reflects the range in estimates of the annual benefits that would be associated with tamarisk removal. Because control costs are incurred gradually over 20 years and benefits begin to accrue near the beginning of this period to accrue near the beginning of this period
(tamarisk is removed in year 2), benefits recovered within the first 18 years would immediately offset control costs. 
control costs throughout the range of estimated annual benefit values (USD 248-447 ha ${ }^{-1}$ ). At discount rates of 1-6\%, benefits keep pace with costs at the high end of the range of benefit estimates. If benefits fall in the low range of estimates, the number of years required to recover costs is sensitive to discount rate and ranges from 28 to 51 years ( 8 to 31 years after the completion of eradication and revegetation). After control and restoration costs have been offset by the accummulating benefits of restored riparian ecosystems in the region, these benefits would continue to accrue indefinitely.

\section{IMPLICATIONS}

While further research and planning would have to precede the adoption of a program of Tamarix eradication in the United States, this study illustrates the likelihood that such a course of action would have clear benefits, economically as well as socially and ecologically. Additional studies of this kind may help to establish that the worsening global problem of biological invasions is likely to be accompanied by serious - and quantifiable-economic damage to the services that natural ecosystems provide.

Economics cannot be the sole measure of the worth of a species, nor the single tool used to guide decisions about ecosys- tem management. However, when social and ecological arguments already militate in favor of a particular action, the finding that economics also favor it makes a compelling case to pursue it. The findings presented here can be considered only preliminary and incomplete estimates of the costs and benefits that controlling Tamarix would incur. The execution of an eradication and restoration campaign would require a detailed partitioning of benefits and costs, perhaps to groups whose responsibility to contribute to control costs may be unclear such as farmers and floodplain residents. The practical challenges of eliminating Tamarix in a coordinated way from throughout its naturalized range (which includes northern Mexico) while preventing recolonization are not trivial.

Conversely, the economic importance of many potential benefits of tamarisk eradication and restoration, from decreased water salinity and groundwater pumping costs to improved recreational revenues, crop pollination, and support for native wildlife, have not yet been evaluated. These values would only strengthen the economic argument in favor of control. The results presented here, hence, strongly suggest that an economic motivation can be added to social and ecological arguments for aggressively eliminating Tamarix from the western United States and restoring the native riparian forests and shrublands that it has displaced over the last century.

\section{References and Notes}

1. Daily, G.C. (ed.). 1997. Nature's Services: Societal Dependence on Natural Ecosystems. Island Press, Washington, USA.

2. Costanza, R., d'Arge, R., deGroot, R., Farber, S., Grasso, M., Hannon, B., Limburg, K., Naeem, S., O’Neill, R.V., Paruelo, J., Raskin, R.G., Sutton, P. and van den Belt, M. 1997. The value of the world's ecosystem services and natural capital. Nature 387, 253-260.

3. van Wilgen, B.W., Cowling, R.M. and Burgers, C.J. 1996. Valuation of ecosystem servces: a case study from South African fynbos ecosystems. BioScience 46, 184-189.

4. Pimentel, D., Wilson, C., McCullum, C., Huang, R., Dwen, P., Flack, J., Tran, Q., Saltman, T. and Cliff, B. 1997. Economic and environmental benefits of biodiversity. Bioscience 47, 747-757.

5. Simberloff, D., Schmitz, D.C. and Brown, T.C. 1997. Strangers in Paradise: Impact and Management of Nonindigenous Species in Florida. Island Press, Washington, DC, USA.

6. U.S. Bureau of Reclamation. 1995. Vegetation Management Study, Lower Colorado River: Phase II Final Report. Bureau of Reclamation, Lower Colorado Region, Boulder City, NV, USA.

7. U.S. Congress, Office of Technology Assessment. 1993. Harmful Non-Indigenous Species in the United States. U. S. Government Printing Office, Washington, DC, USA

8. Center of the American West, University of Colorado at Boulder. 1997. Atlas of the New West. W.W. Norton \& Company, New York, USA.

9. Neill, W.M. 1983. The Tamarisk Invasion of Desert Riparian Areas. Desert Protective Council, Inc., Spring Valley, CA, USA.

10. Morrison, J.I. 1996. The Sustainable Use of Water in the Lower Colorado River Ba$\sin$. The Pacific Institute and the Global Water Policy Project, Oakland, CA, USA.

11. Waggoner, P.E. and Schefter, J. 1990. Future water use in the present climate. In: Climate Change and US Water Resources. Wiley Series in Climate and the Biosphere. Waggoner, P.E. (ed.). Wiley \& Sons, New York, pp. 19-40.

12. Nash, L.L. and Gleick, P.H. 1991. Sensitivity of streamflow in the Colorado Basin to climatic changes. J. Hydrol. 125, 221-241.

13. Baum, B.R. 1978. The Genus Tamarix. Israel Academy of Sciences and Humanities, Jerusalem, Israel.

14. Walker, L.R. and Smith, S.D. 1997. Impacts of invasive plants on community and ecosystem properties. In: Assessment and Management of Plant Invasions. Springer Series on Environmental Management Luken, J.O. and Thieret, J.W (eds). Springer, New York, USA. pp. 69-86.

15. Brock, J.H. 1994. Tamarix spp. (Salt Cedar), an invasive exotic woody plant in arid and semi-arid riparian habitats of western USA. In: Ecology and Management of Invasive Riverside Plants. Landscape Ecology Series. deWaal, L.C., Child, L.E., Wade, vasive Riverside Plants. Landscape Ecology Series. deWaal, L.C., Child, L.E., W
P.M. and Brock, J.H. (eds). John Wiley \& Sons, Chichester, England. pp. 27-43.

P.M. and Brock, J.H. (eds). John Wiley \& Sons, Chichester, England. pp. 27-43.
6. Everitt, B.L. 1980. Ecology of saltcedar: a plea for research. Environ. Geol. 3, 77-84.

17. Robinson, T.W. 1965. Introduction, Spread, and Areal Extent of Saltcedar (Tamarix) in the Western States. US Geological Survey, Washington, DC, USA.

18. Great Western Research. 1989. Economic Analysis of Harmful and Beneficial Aspects of Saltcedar. Bureau of Reclamation, Mesa, AZ, USA.

19. Warren, D.K. and Turner, R.M. 1975. Saltcedar seed production, seedling establishment, and response to inundation. Arizona Acad. Sci. 10, 131-144.

20. Loope, L.L., Sanchez, P.G., Tarr, P.W., Loope, W.L. and Anderson, R.L. 1988. Biological invasions of arid land reserves. Biol. Conserv. 44, 95-118.

21. Shafroth, P.B., Friedman, J.M. and Ischinger, L.S. 1995. Effects of salinity on establishment of Populus fremontii (cottonwood) and Tamarix ramosissima (saltcedar) in southwestern United States. Great Basin Natural. 55, 58-65.

22. Cleverly, J.R., Smith, S.D., Sala, A. and Devitt, D.A. 1997. Invasive capacity of Tamarix ramosissima in a Mojave Desert floodplain: the role of drought. Oecologia 111,1218 .

23. Busch, D.E. and Smith, S.D. 1995. Mechanisms associated with decline of woody species in riparian ecosystems of the southwestern U.S. Ecol. Monogr. 65, 347-370.

24. Wiesenborn, W.D. 1996. Saltcedar impacts on salinity, water, fire frequency, and flooding. In: Proc. Saltcedar Management Workshop. Rancho Mirage, CA, USA pp. 9-12.

25. Busch, D.E. and Smith, S.D. 1993. Effects of fire on water and salinity relations of riparian woody taxa. Oecologia 94, 186-194.

26. Johns, E.L. 1990. Vegetation Management Study, Lower Colorado River: Appendix 1, Water Use of Naturally Occurring Vegetation. Bureau of Reclamation, Denver, CO, USA.

27. Blackburn, W.H., Knight, R.W. and Schuster, J.L. 1982. Saltcedar influence on sedimentation in the Brazos River. J. Soil Water Conserv. 37, 298-301.

28. Graf, W.L. 1980. Riparian management: a flood control perspective. J. Soil Water Conserv. 35, 158-161.

29. Graf, W.L. 1978. Fluvial adjustments to the spread of tamarisk in the Colorado Plateau region. Geol. Soc. Am. Bull. 89, 1491-1501.

30. DeLoach, J. 1997. Saltcedar; ecological interactions and potential effects of biological control. In: Woody Plant Wetland Workshop, Grand Junction, CO, USA

1. Nabhan, G.P. and Buchmann, S.L. 1997. Services provided by pollinators. In: Nature's Services: Societal Dependence on Natural Ecosystems. Daily, G.C. (ed.). Island Press, Washington, USA, pp. 133-150.

32. Brown, B.T. and Trosset, M.W. 1989. Nesting-habitat relationships of riparian birds along the Colorado River in Grand Canyon, Arizona. Southwestern Natural. 34, 260 270 .

33. Yong, W. and Finch, D.M. 1997. Migration of the willow flycatcher along the Middle Rio Grande. Wilson Bull. 109, 253-268.

34. DeLoach, C.J. 1997. Biological control of weeds in the United States and Canada. In: Assessment and Management of Plant Invasions. Luken, J.O. and Thieret, J.W. (eds). Springer, New York, pp. 172-194.

35. Colby, B.G. 1989. Estimating the value of water in alternative uses. Nat. Res. J. 29 , 511-527.

36. Colby, B.G. 1989. The economic value of instream flows - can instream values compete in the market for water rights? In: Instream Flow Protection in the West MacDonnell, L.J., Rice, T.A. and Shupe, S.J. (eds). Natural Resources Law Center, Boulder. pp. 87-102

37. Gibbons, D.C. 1986. The Economic Value of Water. Resources for the Future, Washington, DC, USA

38. Young, R.A. 1984. Local and regional economic impacts. In: Water Scarcity: Impacts on Western Agriculture. Englebert, E.A. and Schuering, A.F. (eds). University of California Press, Berkeley, pp. 244-272.

39. U.S. Bureau of Reclamation 1992. Vegetation Management Study_Lower Colorado River, Phase I. Bureau of Reclamation, Lower Colorado Region, Boulder City, NV, USA.

40. DeLoach, J. 1997. Biological control of exotic saltcedar in western riparian areas. In: Woody Plant Wetland Workshop, Grand Junction, CO, USA

41. Taylor, J.P and McDaniel, K.C. 1998 . Restoration of saltcedar infested flood plains on the Bosque del Apache National Wildlife Refuge. Weed Technol. 12, 345-352.

42. The author would like to thank Hal Mooney, Roz Naylor, Peter Vitousek, David Ackerly, John O. Niles and Michael Goldbach from Stanford University for their helpful comments and assistance.

43. First submitted 29 Dec. 1999. Accepted for publication after revision 27 April 2000.
Erika Zavaleta is with the Department of Biological Sciences ecological and societal impacts of interacting, human- address: Dept. of Biological Sciences, Stanford University, Stanford, CA 94305-5020, USA E-mail: erika@jasper.stanford.edu 